\title{
Navigating the 'dark waters of globalisation': Global markets, inequalities and the spatial dynamics of risk
}

\author{
Denis Fischbacher-Smith ${ }^{\mathrm{a}, *}$ and Liam Smith ${ }^{\mathrm{b}}$ \\ ${ }^{a}$ Adam Smith Business School, University of Glasgow, Glbert Scott Building, \\ West Quadrangle, Glasgow G128QQ, UK. \\ bDepartment of Geography and Planning, University of Liverpool, \\ Jane Herdman building, Liverpool L69 3GP. \\ *Corresponding author.
}

\begin{abstract}
The links between the processes of globalisation and the generation of risk have been brought into sharp focus as a function of a series of accidents and terrorist attacks on Western interests and their supply chains. The increasingly interconnected nature of organisations, the dependence of western economies on a set of global supply chains, the export of hazardous goods and services, and the recruitment of staff from a global recruitment pool, all generate the potential for new forms of hazard and require organisations to reconfigure and extend the capabilities of their control and monitoring systems. Our aim in this article is to review the challenges that globalisation processes can generate for organisational effectiveness and, in particular, on the performance of processes around risk management and the prevention of crises.
\end{abstract}

Risk Management (2015) 17, 179-203. doi:10.1057/rm.2015.12

Keywords: risk and crisis management; globalisation; organisational effectiveness; enterprise risk management

The online version of this article is available Open Access

\section{Introduction}

There is a bitter irony in that the fruits of globalisation - technology, free international trade - have been turned into weapons against the globalised 
economy by those whom globalisation has failed. There is perhaps no better illustration of the dark side of globalisation than the deadly juxtaposition of hungry, qat-chewing men toting Kalashnikovs and computerised navigational technology.

(Brannigan, 2013)

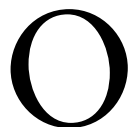

ur focus in this article is with the 'dark side' of globalisation highlighted by Brannigan and its impact on risk management. The article's title came from a chance conversation with another colleague who, when one of the authors produced a branded soft drink, uttered a cry of: 'Ah, the dark waters of imperialism'. While clearly intended as a humorous interjection, it did serve to generate a subsequent series of discussions around the processes of globalisation, their relationships to forms of economic and political imperialism, and the impact that a range of globalising forces can have on both the configuration of risk and the potential for generating subsequent crises for organisations and local populations. The comment, and the discussion that followed, served to highlight the role that Western trans-national corporations play in the generation and export of risk, the exploitation of economically weak countries (and regions) and the creation of dependent markets among poor communities for their products. At the same time, there is also a countercurrent that takes place in the form of resistance, public opposition and, in some contexts, criminal acts. The opening quote from Brannigan also highlights the dichotomy that is often articulated in discussions around globalisation, namely the uneven distribution of the benefits and costs associated with it, and the manner in which certain groups have been 'radicalised' or criminalised into taking action against such (largely Western) global interests. This process of defining such opposition as 'radicalised' is invariably a value judgment and many would frame opposition to globalisation forces in terms of legitimate resistance by those who are exploited and oppressed by powerful corporations (Routledge, 1996, 2000, 2003). Thus, the terrain over which the processes and consequences of globalisation range is clearly an uneven and fractured one. Not surprisingly, this is mirrored in the relationship between globalisation and the generation of risk and crisis.

Although clearly a beneficial process for some, globalisation has also added to the range of spatial inequalities that exist and has, in a number of cases, generated a new portfolio of hazards. These hazards have emerged as a consequence of the scale of those economic processes that drive globalisation and have also generated emergent conditions that have provided unintended consequences for both rich and poor states.

Two examples serve to illustrate the complex dynamics of the circuits and flows (Hudson, 2004) that are associated with globalising processes. First, the failure of the sub-prime market, the deregulation of particular markets and the global recession that followed that triggering event, propelled many Western 
countries into a state of crisis and eroded confidence in financial institutions (Owens, 2012). This crisis illustrated the limitations of key assumptions around increases in the value of house prices, the willingness of individuals to incur debt and the effectiveness of governance and control mechanisms that were supposed to be in place to manage the behaviours of financial institutions. The crisis also illustrated the subsequent difficulties that governments faced in trying to contain the impact of the collapse and highlighted the problems that exist around the limitations of technical expertise when dealing with low-probability, high-consequence events. The sub-prime crisis also typified the difficulties associated with risk prediction when the uncertainty within the information available to decision makers around cause-and-effect relationships is high. As a consequence, assumptions were made around the perceived key risk parameters but these had weak predictive capability, especially given the lack of prior experience with these risk factors. Expert judgments and the determination of the burden of proof around the probability and consequences of failure also sit at the core of the sub-prime crisis. The interconnected nature of the financial markets saw the crisis irradiate a number of Western economies and it exposed a series of underlying structural weaknesses within trading blocs such as the European Union. Financialisation has been seen as changing the underlying processes of the economy and can be seen as linked to the processes around globalisation, although the nature and significance of these relationships have been contested (Dore, 2008; van der Zwan, 2014; Aalbers, 2015; Christophers, 2015; Lawrence, 2015). There is a view that sees the processes around financialisation as generating risk through the power of technical expertise and increased volatility within the system (Pike and Pollard, 2010) and that has resulted from the 'tightly coupled' and 'interactively complex' (Perrow, 1984) nature of the finance sector. The risks associated with financialisation, especially those processes exposed in the 2008 crisis, have highlighted the spatial dynamics of the harm that is generated through the various circuits and flows of capital (Wainwright, 2012, 2013). Invariably, these spatial and temporal processes have generated problems around the governance of the sector and the controls available to deal with trans-national capital. Despite concerns expressed around the underlying cultural factors that impacted upon the crisis, changing the culture of the finance sector has proved to be difficult (Wilmarth, 2009; Ashby, 2011; Kerr and Robinson, 2011; Vaiman et al, 2011).

The second example also highlights the difficulties associated with governance and control. The 'dark waters' referred to in the title of the article have another, perhaps more sinister meaning, as they point to the problems that have emerged in the last 20 years relating to the increased risks from piracy, criminal behaviours and terrorist activities across global supply chains (Barnes and Oloruntoba, 2005). While piracy and crime are not new phenomena, the sense of injustice, the generation of failed nation states, the increased opportunities 
for crime generated by globalisation and the lack of legitimate economic opportunities for local communities are often held as key drivers for the re-emergence of such 'criminal acts'1 (Leeson, 2009; Murphy, 2009; Pham, 2010). A range of issues around increased conflict, environmental impacts and the emergence of powerful crime lords have led to further exploitation of local, already impoverished, communities and provided drivers into piracy and, in some cases, terrorism (Kavanagh, 2011; Daxecker and Prins, 2013; Jablonski and Oliver, 2013).

Both of these examples highlight the pluralist nature of globalisation and the manner in which it impacts upon, and is shaped by, the various domains associated with it. For Rennen and Martens (2003), these domains include socio-cultural factors, economic drivers, environmental dynamics and the political context in which these processes occur. The increased development of communications and transport technologies has also been seen as important drivers of the globalisation process (Cairncross, 2001; Rennen and Martens, 2003). The complex nature of the circuits and flows that links these domains together generates emergent conditions as a function of new forms of interaction. Invariably, this emergence will manifest itself in new operating conditions that move the system outside of its designed-for control parameters, or it will create hazards that had not be considered as likely or viable before the effects of these emergent conditions became realised.

These emergent forms of risk form part of a wider mosaic of hazards that are seen as being imposed upon local populations within a globalised setting. The communities that host such hazards are often poorly equipped to actively oppose them through legitimate means - that is, economically, politically and scientifically - and so often have to revert to actions that are deemed to be illegitimate or illegal by both Trans-National Corporations (TNCs) and foreign governments. This then serves to criminalise these already disadvantaged communities as they resist exploitation (Idemudia and Ite, 2006; Watts, 2007; Obi, 2010). The dark side of globalisation has, therefore, generated a multi-level, asymmetric set of issues that have, in some cases, served to generate further problems and unintended consequences. Increasingly, the debates around globalisation have concerned its role in generating new forms of hazard, changing the distributions of the hazards that exist or providing additional scope for intervention when catastrophic failures occur. A central tenet of these discussions concerns the relationships between the drivers and processes surrounding globalisation and the generation of risk at multiple points in space and time.

Our aim in this article is to consider whether the processes around globalisation have generated hazards that lie outside of more traditional approaches taken to risk management. The challenges here can be seen to group around three main issues. First, the potential hazards facing organisations need to be assessed in a holistic manner. Because of the distances over which activities are 
carried out, reductionist approaches to managing risk are unlikely to capture the potential for emergent conditions, especially across different environmental settings. Second, the circuits and flows that underpin globalisation (Hudson, 2000) generate additional hazards through the vulnerability of supply chains (Peck, 2005; Manuj and Mentzer, 2008). Third, local populations can react negatively to the actions of trans-national organisations and this can cause local forms of resistance that are both disruptive and damaging to an organisation's reputation, especially as groups increasingly use social media as a means of engaging public support for that local resistance (Mackey, 2015). In order to frame these challenges for risk management, we need to contextualise them within the wider set of processes around globalisation. Our aim is to set out the parameters in which more holistic approaches to risk need to be carried out. The remainder of the article sets out the contexts in which the various spaces of production and consumption (Hudson, 2000, 2001, 2004) give rise to destructive processes.

\section{The Nature of Globalisation? Elements of a Debate}

Globalization encompasses many things: the international flow of ideas and knowledge, the sharing of cultures, global civil society, and the global environmental movement ............ globalization has the potential to bring enormous benefits to those in both the developing and the developed world. But the evidence is overwhelming that it has failed to live up to this potential.

$$
\text { (Stiglitz, 2006, p. 4) }
$$

While the creation of markets for goods and services is part of the natural order of business, there are some products and services that are clearly problematic and exploitative and which have the potential to cause harm. These range from the export of hazardous materials and processes through to the creation of new markets for products that are both harmful and heavily restricted in many traditional markets in Western countries. One obvious example of the latter is the export of cigarettes and the ways in which tobacco companies seek to circumvent local restrictions and controls to create new markets (Gruner, 1996; Yach and Bettcher, 2000; Gilmore and McKee, 2004; Lambert et al, 2004). Problematic exports are not, however, restricted to those that have hazardous consequences. It is possible that even some basic commodities, and those that have clear health benefits (Sridharan and Viswanathan, 2008; Cross and Street, 2009; Weidner et al, 2010), can also generate unforeseen consequences. For example, the distribution of soap into extremely poor communities can have extremely positive health benefits, as hand-washing is seen as an essential element in gastrointestinal disease reduction (Curtis \& Cairncross 2003; Shahid et al, 1996). However, if these soap products are priced at a level that the poorer sections of society cannot afford them in the longer term then it can generate a 
series of reputational problems in terms of the ways in which such products are marketed (Gupta and Jaiswal, 2013). The blowback generated in such cases is largely in terms of reputational damage as, despite the positive intentions associated with introducing soap into such environments, critics of TNCs will invariably see it in terms of building market share and exploiting the poor. So, unless products are priced according to the economic context prevailing in the locations where they are introduced, then companies may be faced with additional reputational risks.

Globalisation also supports two-way flows and there is a counter-current of goods that are exported (often illegally) into Western markets and which sometimes fail to meet stringent local standards or are possibly counterfeit. Examples include digital and pharmaceutical counterfeiting (Aldhous, 2005; Banerjee et al, 2005), with the latter resulting in deleterious health effects and, some cases, their coexistence with legitimate products within a retail environment. $^{2}$ These illicit trades often utilise the same technologies and transport mechanisms that support globalisation and they generate significant challenges for regulatory agencies around governance and control. For the company whose branded products are counterfeited, this also creates additional challenges around brand integrity and the possible generation of reputational crises.

The flows and counter-flows that underpin globalisation serve to generate hazards at multiple levels within the system. The circuits and flows of people, information (including ideologies) and resources also have the potential to generate emergent conditions that can exceed the control mechanisms that are put in place to prevent harm. These complex 'circuits of capital' (Hudson, 2004, 2009) can, for example, serve to generate a landscape of imbalances in which the potential exists for criminal groups to exploit fractures in controls that arise over an extended sphere of operations. This has changed the nature of the managerial challenges around organisational controls, human resource recruitment and management, as well as the provision of organisational security. Figure 1 illustrates the broader nature of this process and provides a context for our discussion here.

These flows can invariably be one- or two-way and the flow patterns may be bi-lateral, constrained or restricted. In addition, these circuits and flows may be legal or illicit (Hudson, 2009, 2014). As such, the flows and circuits of 'capital' within and between the various spaces of production and consumption can be complex (Hudson, 2000) and, as a consequence, generate the potential for emergent conditions that arise out of those interactions. The resultant 'spaces of destruction' can extend over time as the impacts associated with this range of activities can be either immediate- or delayed-in-effect (Fischbacher-Smith, 2011). This dynamic environment creates managerial challenges for organisations and invariably generates fractures in control and governance arrangements. There are, for example, considerable risks associated with the recruitment and selection processes that are increased within a global market. 


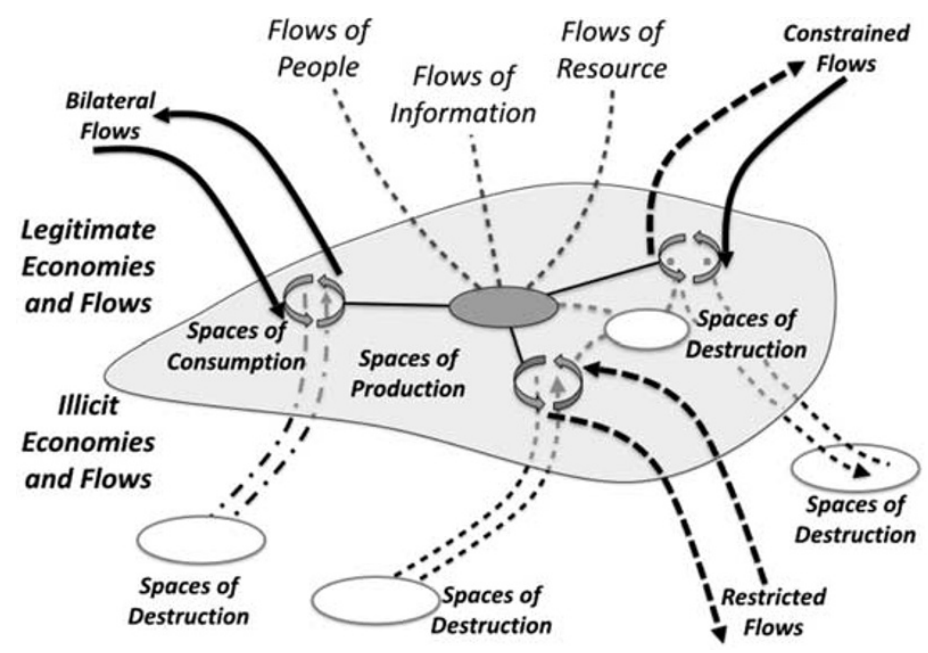

Figure 1: Flows and counter-flows within globalisation.

While much of the discourse within business and the academy is around the selection of 'global talent' (Tarique and Schuler, 2010; Schuler et al, 2011; Sparrow, 2012) there is, at the same time, an increased set of risks associated with the threats from insiders and the challenges in vetting and approving staff appointments within such a global setting (Warkentin and Willison, 2009; Minbaeva and Collings, 2013; Holdaway, 2014; Fischbacher-Smith, 2015). The advances in communications technologies, and the ability to store large volumes of data on relatively small devices, has also increased the scale of potential harm that insiders can cause. This point was so forcefully illustrated by the ability of Edward Snowden to download considerable amounts of highly sensitive information from within a supposedly secure environment (Greenwald, 2014; Gurnow, 2014). Increased capability around communications and data sharing, although generally a positive process, also serves to increase the potential risks from hacking, the threats associated with the coercion of staff by outsiders and the willingness of disenfranchised colleagues to cause harm. Advanced communication technologies can provide the means for criminal groups to undertake illegal acts. This is often done at a distance and beyond the 'normal' reach of Western police and security agencies. If we add to this the increased distances over which TNCs operate, then the potential points of vulnerability around infiltration and data theft can be seen to increase considerably. The extended supply chains of organisations also increases the potential vulnerabilities that are embedded in control systems. Globalisation can, therefore, be seen to have contributed to the creation of a complex mosaic of hazards and the disproportionate distributions of costs and benefits associated with the opening up of markets. 
Where people and valuable resources are transported through, or in close proximity to, disadvantaged areas, the opportunities for piracy, kidnapping and theft may also attract the attention of the criminally minded. Economic forces also generate the movements of people as they seek to improved their economic standing or escape from conflict zones. While the movement of people within coalitions, such as the European Union, is generally seen as a positive processes for the recruitment of global talent, it also risks generating a population of the disenfranchised who are unable to find work and who blame immigrant workers for that. As the problems at Calais and across the Mediterranean in 2015 have also highlighted, the diasporas of the dispossessed that arise from both armed conflicts and economic crises can also be considerable. Again, this movement and displacement of people is both fuelled, and supported, by globalising forces.

The article now turns to consider the processes that underpin the generation of hazards within the context of the production-consumption-destruction (P-C-D) framework. The dominant approach here draws heavily on a systems perspective in dealing with the processes around enterprise-related risk. The remainder of the article attempts to illustrate how the various elements in the P-C-D framework interact with each other and how the evolution of the system can move it away from its designed for state into one that exceeds the parameters of control.

\section{A System of Destruction}

Figure 2 seeks to conceptualise these processes by integrating the various spaces of production and consumption (Hudson, 2000, 2001, 2004) with the notion of spaces of destruction (Fischbacher-Smith, 2011). These spaces are linked together in time by both legitimate and illicit flows that are facilitated, in turn, by a range of underpinning technologies. The result is that destruction becomes manifest in various places over time within the wider system. Many of these processes are difficult to observe in real-time because of their multi-layered nature and the temporal effects that serve to cloak cause-and-effect relationships. Figure 2 attempts to illustrate these interactions and highlights the role of both legitimate and illicit flows within the generation of destruction. The key processes here can be seen to group around three key theoretical overlapping constructs. The first is the notion of incubation and error cost (Turner, 1976, 1978, 1994; Collingridge, 1980, 1992) in which the potential for failure is generated as a function of the routine decision-making processes within an organisation. These 'latent conditions' can then be exposed by more operational forms of human error or violations (Reason, 1990,1997, 2000) or by the compression of time horizons within the functional elements of the systems processes (Radell, 1992). The second set of processes that are important here 


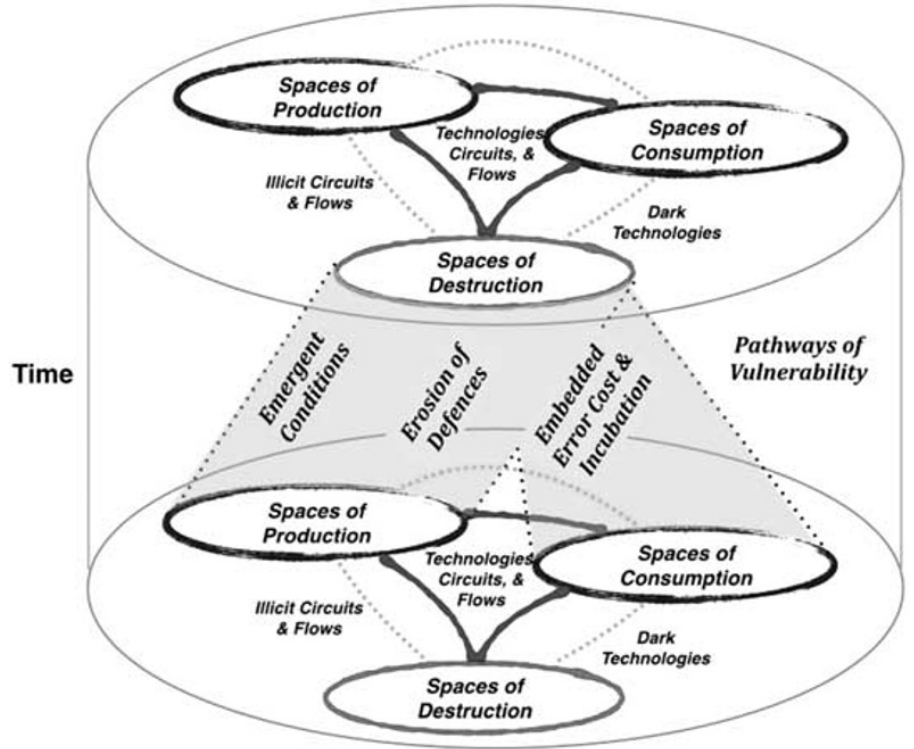

Figure 2: A system of destruction.

relate to the erosion of systems defences, either by an act of omission or commission, so that triggering events can escalate to cause catastrophic failure (Perrow, 1984; Reason, 1987; Turner, 1994; Tenner, 1996). The final set of processes concerns the role of emergent conditions in generating new forms of threat or failure conditions for which no controls exist (Erikson, 1994; Fischbacher-Smith, 2014). These emergent conditions can move a system away from its designed-for state into a new operating state that lies outside of its normal control parameters (Tsoukas, 1999; Hodge and Coronado, 2007). Moving a system to a new equilibrium state can generate vulnerabilities because of constrained sensemaking processes and the lack of effective control that it can generate (Weick, 1988, 1990, 1993). In many cases, the cost associated with these error-producing conditions only becomes obvious much further down the decision time-line. Over time, these processes can generate pathways of vulnerability (Smith, 2005) in which the incubation of risk potential occurs as a function of the routine decision-making processes within the organisation (Turner, 1976) and where human errors (both latent and active), along with violations, can serve to erode the organisational defences that are in place (Collingridge and Reeve, 1986; Collingridge, 1992; Reason, 1997). This is particularly problematic when the organisations concerned operate across increased geographical distances and scale (Collingridge, 1992). The outcome of these processes is that organisations are moved away from their designed-for state into an equilibrium state that is outside of the established control parameters for the organisation and its core activities. 
Within the interactions outlined above, the errors that are generated need to be considered in both strategic and operational terms and can also be a function of both accidental and intentional acts, where the costs of those errors are only recognised in other places or in future systems states. A central dynamic here is the role of expert judgement in shaping the nature of those decisions and the recognition that expertise is limited when dealing with low-probability, high-consequence events. Expertise plays a role across the P-C-D framework and is also an important element in dealing with the technologies, circuits and flows that drive and shape these various 'spaces'. The ability of organisations to design and manage the system of production-consumption and the associated circuits and flows is often functionally dependent on the flows of information and expertise and the utilisation of the knowledge that arises out of those interactions. However, as the financial crash has illustrated, the knowledge base associated with low-probability, high-consequence events is often problematic and the predictive capabilities of organisational decision makers is weak as a consequence. Another important element here relates to the trust that decision makers have in those experts who provide advice and guidance and the effectiveness of regulatory and governance arranges in preventing unacceptable risk-taking (Dore, 2008; Olsen, 2011; da Veiga et al, 2012).

Against this broad background, Stiglitz (2006) also highlights a number of aspects of globalisation that can be seen to have negative consequences and that need to be considered in more detail within our present discussions. The first of these concerns the International flow of ideas and knowledge (Stiglitz, 2006). In and of itself, this can be seen as a positive process as it can challenge many of the outdated ideas and superstitions that exist in many parts of the world. The Ebola outbreak in 2014-2015 highlighted the suspicions that some communities have about Western forms of medicine (Briand et al, 2014) and the problems surrounding local health infrastructures attempting to contain virulent disease outbreaks (Koroma and Lv, 2015). Here globalisation is a double-edged problem. It allows for additional resources to flow into an infected area but it also generates the potential for the infection to be transmitted globally because of the flows of people via international travel (Wilder-Smith and Gubler, 2008). In contrast, the flows of information and knowledge, which should be important elements in the erosion of beliefs within many of the poor African nations, failed to address some of the problems around witchcraft and superstition as elements in disease transmission (Tenkorang et al, 2011). Similarly, globalisation has often failed to improve the general awareness around public health, despite the promised increases in education and communication that it offers. The flow of ideas and information also played a major role in the Arab Spring, as local groups utilised social media to share information and concerns about the established order in a number of Middle Eastern countries (Eltantawy and Wiest, 2011; Khondker, 2011). Out of this disruption, there also emerged a set of drivers that coalesced around 
revolutionary change (Joffé, 2011; Kamrava, 2012; Bayat, 2013; Lynch et al, 2014) and these may well have served to help sustain the growth in the so-called Islamic State (ISIS), and especially its use of social media (Bradley, 2012; Farwell, 2014; Klausen, 2014; Stansfield, 2014). ISIS have effectively used social media to attract recruits from across Europe and the Middle East to their cause, and to promote their particular message of fundamentalist Islam (Atran et al, 2014; Stansfield, 2014). ISIS has also used one of the core elements of globalisation - the flow of ideas and knowledge though electronic forms of communication - against the West and, although not the first such group to use this approach, they have arguably been the most successful. Far from providing for the transmission of a common set of largely Western values, globalising forces have been instrumental in allowing anti-Western and anti-globalisation sentiments to gain widespread traction.

The second and related issue identified by Stiglitz concerns the range of processes associated with 'the sharing of cultures' (p. 4). The forces of globalisation can be seen to have a goal of potentially homogenising cultures (invariably, as critics suggest, around a US model) rather than allowing for a two-way sharing. It effectively subsumes the cultures in those countries, which it 'invades' and seeks to convert them to a set of largely Western values in what could be seen as an attempt at a cultural hegemony. What this process generates are various forms of resistance by local communities. There have been several examples of this resistance to globalisation (Routledge, 1996, 2000; Chin and Mittelman, 1997) and this pushing back has become all the more apparent in the wake of the so-called 'war on terror' that was prosecuted after the attacks of 11 September. The current problems in Iraq, the rise of ISIS and the migrations of young people to fight for, and against, ISIS all point to the problems that can arise when the sharing of culture via globalisation is seen as little more than an attempt to supplant local cultures with Western values. The backlash to this often serves to push that culture towards a more fundamentalist extreme. Again, this process of blowback (Bergen and Reynolds, 2005) - a form of the law of unintended consequences - is a powerful factor in shaping resistance and generating emergence. The upsurge in nationalism in certain countries and the difficulties that exist in large economic blocs such as the European Union, highlight the different ways in which the effects of globalisation can generate both emergent conditions and economic inequalities that can fuel a nationalist agenda. This has been brought into sharp focus with the economic problems faced by Greece, which have generated considerable resentment against the main agencies of globalisation as perceived by local actors. The power of international capital to shape local conditions within countries have also led to calls to resist the imposed austerity cultures that these agencies demand to deal with national deficits.

Stiglitz also highlights the importance of international networks in raising concerns about environmental impacts. The 1980s saw the emergence of 
debates around the export of hazardous activities that highlighted the ways in which organisations would seek to exploit gaps in regulatory frameworks and differences in operating costs (Shrivastava, 1987). The accidents at Bhopal and Chernobyl also highlighted the potential that existed within socio-technical systems to cause mass fatalities and both accidents also illustrated the tensions around different regulatory frameworks for the controls of such hazards. Cherobyl highlighted the potential Hans-boundary effects of a major radioactive accident and the difficulties associated with the implementation of effective global standards for performance and safety. Bhopal highlighted the potentially exploitative nature of Western TNCs who actively sought to export hazardous activities and materials to regulatory regimes that were much weaker (Smith and Blowers, 1992). Thirty years later, similar processes can be seen to be still at work but the risks that they generate are different (Idemudia and Ite, 2006; Hudson, 2009, 2014). While the presence of a 'global environmental movement' (Stiglitz, 2006, p. 4) can generally seen as a positive force associated with globalisation, it also reflects the potential that exists for other forms of networks, some of which may have malevolent intent, to use the tools of globalisation (especially the freedom of travel, communications technologies, and processes around knowledge exchange) as a means of opposing that wider process (Daxecker and Prins, 2013; Lemieux et al, 2014). Friedman argues that the current stage of the globalisation process is increasingly typified by the collaboration of individuals in distributed networks in a 'flat world platform' (Friedmann, 2006) in which the accumulation and transfer of knowledge will allow for new forms of collaboration, some of which may be destructive (Friedman, 2005). The presence of the so-called 'dark web' (Chen et al, 2008) highlights the destructive conditions that can be created by such technological advancement when it is used for criminal activities (Xu et al, 2006; Etges and Sutcliffe, 2008; Fu et al, 2010). The 'hidden' layers of the Internet provide a space for the range of illicit activities leading to an ongoing arms race between law enforcement agencies and those who seek to break the law. Hudson (2014) argues that there is a strong link between the development of those capitalist economies that are the driving force behind globalisation and a range of associated illegal activities. He likens this relationship to one in which:

The legal and illegal are locked into a systematic symbiotic relationship which is contingently expressed in and constituted through their patterning in time and space and in the relationships between their flows, paths and spaces.

(Hudson, 2014, p. 775)

These legal and illegal economic drivers interact together to create a set of circuits of capital that underpin a range of risk-generating problems that cause harm to both people and processes. The combination of the flows (ideas, knowledge, ideology, people and products) and these circuits of capital are 
aided by the development of dark technologies to create mechanisms for generating and sustaining flows that remain hidden to those regulatory authorities that seek to constrain them. These dark technologies and the use of such financial transfer mechanisms as Bitcoin serve as a means of by-passing international controls (Chen et al, 2008; Stevens, 2009; Keene, 2011; Bronk et al, 2012; Stokes, 2012) and create challenges for legal systems on a global scale (Pocar, 2004; Grabosky, 2007). Again, the Internet has aided in this process and has hastened the creation of illegal international supply chains for illicit goods (drugs, firearms), the trafficking of people, and a range of counterfeit products that often intermingle with legitimate ones at the point of sale (Wertheimer et al, 2003; Aldhous, 2005; Dégardin et al, 2014). Thus, the asymmetry within the process (where small groups are able to challenge the cultural and economic hegemonies of larger, more powerful nations and organisations) is aided by the emergent conditions that are generated as a result of these interactions between globalising technologies.

\section{The Dark Drivers of Harm}

Figure 3 highlights those key dark drivers of the globalising process that can be seen to generate the potential for a range of hazards. It is the interactions between these elements that serve to generate the complex landscape of risks that arise from globalisation and that occur over space and time. These 'spaces of destruction' (Fischbacher-Smith, 2011) are shaped by a range of interactions between these drivers that can then produce associated 'pathways of vulnerability' (Smith, 2005) through which harm can be generated. The manner in which those hazards are incubated (Turner, 1976) takes on a different perspective within a globalised context where the potential for emergent conditions and asymmetry is high and where the identification of local forms of failure is problematic.

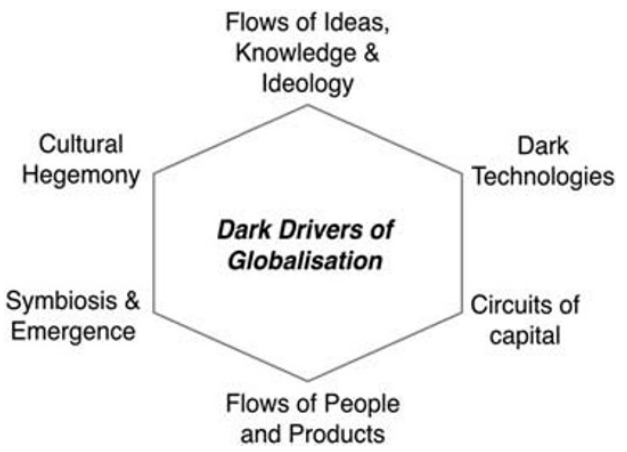

Figure 3: The dark drivers of globalisation. 
Firstly, there are different perceptions relating to the range of pervasive processes around globalisation. The movement of goods, services, labour and capital, contributes to the creation of a market in which inputs and outputs are brought together across multiple locations to allow goods, and increasingly services, from different parts of the world to coalesce in a particular setting. These exploitative processes - such as, the increased activities in people trafficking, the movement of arms and the globalised nature of the narcotics trade - are not new but they have been enhanced by technological developments and global economic imbalances (Castells, 2010; Hudson, 2014). These dark processes around globalisation are also important elements of that wider phenomena. Whether one depicts these relationships to be the reaped benefits of an all encompassing, beneficial and inevitable process of globalisation or the remnants of an imperialistic and exploitative system, which disempowers the vulnerable, will be a reflection of the ideological stance from which one makes sense of the processes involved. Whatever the stance taken, globalisation clearly helps to create interdependencies between elements of production and consumption systems, and allows fractures in controls within globalised organisations to go largely unnoticed unless and until, the system fails catastrophically.

Secondly, these processes can be seen to generate a range of consequences, the most obvious being environmental impacts, that transcend control mechanisms (either intentionally or as an 'accidental' or emergent condition), and that cause differential forms of harm across a global landscape. The costs and benefits of these processes are borne by different social groupings. Although such differential effects are not new, the scales over which they operate have increased as a function of globalising processes.

Thirdly, the obsession with the global market as an engine of economic growth has also served to shape and possibly undermine the nature of accountability and governance. These should be cornerstones of the risk management process but they are severely eroded when the potential sources of hazard transcend different regulatory regimes and where there is no agreement on international standards of performance around many aspects of risk. Of course, for most of us living in Western democratic environments, we take many of the positive benefits around globalisation for granted. We can see the benefits associated with a global supply chain for the goods and services that we depend on and we rarely face the consequences of those risk-generating processes. As a result, many of the demands for greater controls and governance come from those poor communities who are directly affected by these hazards but who are also the least able to effect change. The conflicts around oil production in the Niger Delta provide an example of this issue (Idemudia and Ite, 2006). Western countries are often only mobilised into action when the hazards impact directly on them (often in the form of terrorism or crime) or where social media has been used to galvanise public support. A recent example 
of such public advocacy concerns the pressure brought ${ }^{3}$ against Unilever following a Mercury spill from one of their plants in India (Mackey, 2015).

Fourthly, there is also a hegemonic aspect of the globalising processes, in which countries seek to generate influence in an attempt to ensure that they have access to resources. Historically, these processes were associated with the more traditional imperialist states but this has evolved to include other countries and, increasingly, multi-nationals. The agreements reached around resource utilisation often benefit the political elites within the countries concerned, leaving the general population with little benefit and often with much of the costs. Such exploitation can take multiple forms. The most obvious generates a series of potential hazards when Western companies export hazardous process and activities to take advantage of weaker regulatory regimes. The accident at Bhopal in 1984 killed in excess of 3000 people, many of whom lived in poverty in shanty dwellings around the plant. Union Carbide then sought to minimise its financial liabilities for the accident and used its political and economic power to avoid a trial in the US Courts where the damages would have bankrupted the company. Instead, it fought to have the case heard in India. More recently, concerns about the safety of clothing sweat shops producing goods for Western markets have reignited concerns around exploitation (Radin and Calkins, 2006; Brown, 2015). The emergence of stricter governance arrangements, fair trade policies and social media activism in some Western countries have gone some way towards addressing these forms of exploitation but they have only scratched the surface of what remains a deep-rooted problem.

Finally, globalisation has also changed the demands relating to expert judgments within risk assessments. The range of cultural settings over which organisations work is often considerable and it requires a widening and a deepening of the expert base within organisations in order to address specific local conditions. The manner in which we judge expertise across such different settings is also an issue that has implications for decision making around risks, especially where there is no real actuarial basis upon which the risk judgements are made. Thus, the nature of evidence, the validity of expert judgement, the separation in space of experts from the entities that they judge, and the increasing role of so-called big data, are all challenges that face organisations around the management of risk and uncertainty.

\section{Challenges for Holistic Risk Management}

Against this background, organisations have sought new ways of dealing with the management of risk that adopts a more holistic approach. Although enterprise risk management (ERM) and, more latterly, resilience have sought to take such a holistic approach, there are still conceptual and practical challenges facing such perspectives. The first of these concerns the scale of the 
enterprise involved and the distance over which its activities are undertaken. Both scale and distance generate problems around organisational controls, the recognition of weak signals and the processes by which good governance is maintained over time. The second challenge relates to the complex nature of the interactions that take place between the elements of the production process and the controls that are put in place to deal with variations in performance. Emergent conditions can move the system away from its planned-for state and have the potential to generate a new set of working practices that are dynamic and invariably adapted to by local operators. If local violations of practice are carried out 'to get the job done' and they are not formally reported to senior management, then this emergent equilibrium state will invariably not be captured either by those who designed the system or those who manage it. Scale and distance can mitigate against effective reporting and governance. The third challenge concerns the processes by which information is managed across the breadth of the enterprise. Not only does this information have to be captured, effectively codified so that it makes sense to others, and disseminated, but it also has to allow for changes to be made to the functioning of the system in a way that ensures effective feedback is in place. In addition, the enterprise has to be certain that the very information technologies that enable it to function effectively and at a distance, are not the source of an additional set of risks. These risks can include data loss, as clearly illustrated by the case of Edward Snowden (Greenwald, 2014), as well as the risks associated with the hacking of key control technologies or the loss of underpinning infrastructures (Chee-Wooi et al, 2008). Within a globalised setting, there are cultural as well as distance-related factors that can mitigate against effective communication and information sharing. Constraints around information flows can be especially problematic when it involves the performance of those critical infrastructures that are essential to the enterprise but which lie outside of its control (Boin and Smith, 2006; Jenelius et al, 2010). Taken together, these factors require the organisation to undertake a number of steps to ensure that the organisation is able to take the holistic approach that ERM requires.

A first stage in this process is the development of awareness, commitment and competencies around performance management, risk identification and mitigation (Reason, 1993, 1995). This needs to be undertaken across the enterprise and in such a way that it allows for effective objective setting to be carried out, along with the creation of a supportive internal environment for risk management (O'Donnell, 2005). It is the scale and complexity of this taskthe development of the so-called risk appetite within the organisation - that has led some to argue that it is a fundamental flaw in the processes of ERM (Power, 2009). Another key stage in the process is the generation of a minimum technical specification for performance (Cherns, 1976, 1987), against which the management of risk can be evaluated. Again, this is likely to prove problematic at the level of the enterprise because of the scale and cultural 
variations involved. At the outset therefore, it could be argued that effective risk management is undermined by the processes of globalisation and the problems are likely to become compounded when the formal processes of risk identification and assessment are carried out. Here, the diffuse nature of the organisation and the role of emergence across the various circuits and flows that underpin its performance, are likely to generate significant levels of emergent conditions that will require a dynamic form of risk assessment. At the same time, however, this dynamic risk assessment is likely to be hampered by information constraints and a search for technocratic solutions to complex multi-level problems. The resultant 'calculative cultures' (Mikes, 2009) will ensure that the power of technocratic elites is reinforced and this will have the effect of making the decision-making processes around risk management even more opaque.

While the holistic approaches to risk management in a globalised environment that are offered by ERM are seductive, the challenges provided by globalisation, and especially its darker characteristics, will invariably undermine the efficacy of risk management. As a result, risk assessment will always be a flawed, albeit essential, management tool that can identify the parameters of risk within a globalised setting but which cannot hope to provide the detailed granularity that is required across the circuits and flows of people, resources and information within the enterprise.

\section{Conclusion}

Globalisation is a defining element of the age in which we live, and one that appears to play a significant role in embedding the potential for failure and exploitation across a range of places and over time. Many of the problems that will face future generations are currently being incubated as part of processes that underpin globalisation and reside in the interconnecting spaces that are an integral part of the process. This interplay between space, place and time within the configuration of risks adds a further layer of complexity to the generation of such problems as a function of globalisation processes. The power of companies to move across international boundaries has highlighted the difficulties that governments face in seeking to regulate their behaviours. Unless international regulation is developed to deal with some of the more challenging risk issues that relate to globalisation then it is likely that many of the problems - and especially those that arise out of the uncertainty generated across space and time - will continue to develop.

Although the opening up of global markets is seen by some commentators to be creating wealth, thereby lifting some groups out of poverty, it is also seen as a factor in condemning others to environmental degradation, exploitation and the consequences of criminality, oppression and terrorism. The ongoing problems of civil unrest and the Diasporas that they create have dominated the 
news headlines during 2015 and seem set to continue for the foreseeable future. The aftermath of the sub-prime crisis also continues to create problems for many countries as they seek to reduce their deficits by introducing austerity measures. Such austerity policies have, in turn, fuelled an additional movement of people and resources and highlighted the vulnerabilities that many governments faces as a function of their indebtedness to the agents of globalisation.

This article has sought to highlight the importance of the various circuits and flows that are essential to the performance of the wider socio-economic system in which risk is generated. It has argued that the movements of people, resources and ideologies also have a potential dark side that generates new forms of risk. The resultant uneven process of risk-benefit generation has led to the expression of concerns around the role that democratic processes can play within the control of such risks and the viability of existing approaches to risk management in addressing the geographic scales over which many modern enterprises function. Within this context, the role that expertise can play within more holistic approaches to risk remains a contentious issue and particularly so for lowfrequency, high-consequence events. Although expert judgments assume a considerable role in the determination of risk they are also open to abuse by powerful interests (Collingridge and Reeve, 1986; Fischer, 1990, 2000). The result is that a key element of the management of risk in a globalised setting concerns the difficulties in maintaining the processes of governance and control.

The article has argued that the linked spaces of production and consumption can, over time, generate spaces of destruction. The generation of destruction can occur across different timescales and within different geographical settings and this relationship requires a more holistic approach to the identification and management of risk. Within this context, traditional approaches to risk management have failed to provide the capability that is needed to address the multi-level nature of the problems that arise from globalisation. This remains a challenge for the risk management community to address, and one that needs to be carried out both theoretically and practically. Calls for more inclusive approaches to dealing with risk that recognise the limitations of our understanding of the nature of the flows and circuits of capital and the impacts that they can have on emergence and risk have highlighted the concerns that some within society have about our abilities to manage scale and complexity within the processes of globalisation.

\section{Acknowledgements}

The authors would like to acknowledge the comments made on earlier versions of this article by Moira Fischbacher-Smith, Ray Hudson, Alan Irwin and Bob McMaster. Needless to say, all errors of omission and commission remain those of the authors. Elements of the research underpinning this article were supported by a grant from the EPSRC (Grant EP/G004307/1) relating to 
organisational vulnerabilities and the authors would like to acknowledge that support.

\section{Notes}

1 Ultimately, terrorist actions that cause harm are criminal acts. The main differentiating factor is the underlying drivers that shape the behaviours.

2 This point was made to one of the authors under conditions of anonymity. The company concerned had incurred considerable direct and indirect costs in trying to combat this illicit trade in counterfeit pharmaceutical products and remove them from the marketplace.

3 The pressure group 38 degrees mounted a campaign against Unilever following the spillage (home.38degrees.org.uk/2015/08/06/unilever-clean-up-your-mess/).

\section{References}

Aalbers, M.B. (2015) The potential for financialization. Dialogues in Human Geography 5(2): 214-219.

Aldhous, P. (2005) Counterfeit pharmaceuticals: Murder by medicine. Nature 434(7030): 132-136.

Ashby, S. (2011) Risk management and the global banking crisis: Lessons for insurance solvency regulation. Geneva Papers on Risk and Insurance 36(3): 330-347.

Atran, S., Sheikh, H. and Gomez, A. (2014) Devoted actors sacrifice for close comrades and sacred cause. Proceedings of the National Academy of Sciences 111(50): 17702-17703.

Banerjee, D., Khalid, A.M. and Sturm, J.-E. (2005) Socio-economic development and software piracy. An empirical assessment. Applied Economics 37(18): 2091-2097.

Barnes, P. and Oloruntoba, R. (2005) Assurance of security in maritime supply chains: Conceptual issues of vulnerability and crisis management. Journal of International Management 11(4): 519-540.

Bayat, A. (2013) The Arab spring and its surprises. Development and Change 44(3): 587-601.

Bergen, P. and Reynolds, A. (2005) Blowback revisited. Today's insurgents are tomorrow's terrorists. Foreign Affairs 84(6): 2-6.

Boin, A. and Smith, D. (2006) Terrorism and critical infrastructures: Implications for public-private crisis management. Public Money and Management 26(5): 295-304.

Bradley, J.R. (2012) After the Arab Spring: How Islamists Hijacked the Middle East Revolts. New York: Palgrave Macmillan.

Brannigan, P. (2013) Piracy: Navigating the dark side of globalisation. openDemocracy, https://www.opendemocracy.net/paul-brannigan/piracy-navigating-dark-side-of-globalisation-0, accessed 11 June 2015.

Briand, S. et al (2014) The international Ebola emergency. New England Journal of Medicine 371(13): 1180-1183.

Bronk, C., Monk, C. and Villasenor, J. (2012) The dark side of cyber finance. Survival 54(2): 129-142.

Brown, G. (2015) Bangladesh: Currently the worst, but possibly the future's best. New Solutions: A Journal of Environmental and Occupational Health Policy 24(4): 469-473.

Cairncross, F. (2001) The Death of Distance: How the Communications Revolution is Changing our Lives. Boston, MA: Harvard Business School Press. 
Castells, M. (2010) End of Millennium. 2nd edn. Oxford: Blackwell.

Chee-Wooi, T., Chen-Ching, L. and Manimaran, G. (2008) Vulnerability assessment of cybersecurity for SCADA systems. IEEE Transactions on Power Systems 23(4): 1836-1846.

Chen, H., Chung, W., Qin, J., Reid, E., Sageman, M. and Weimann, G. (2008) Uncovering the dark web: A case study of Jihad on the web. Journal of the American Society for Information Science and Technology 59(8): 1347-1359.

Cherns, A. (1976) The principles of sociotechnical design. Human Relations 29(8): 783-792.

Cherns, A. (1987) Principles of sociotechnical design revisted. Human Relations 40(3): 153-161.

Chin, C.B.N. and Mittelman, J.H. (1997) Conceptualising resistance to globalisation. New Political Economy 2(1): 25-37.

Christophers, B. (2015) The limits to financialization. Dialogues in Human Geography 5(2): 183-200.

Collingridge, D. (1980) The Social Control of Technology. London: Pinter.

Collingridge, D. (1992) The Management of Scale: Big Organizations, Big Decisions, Big Mistakes. London: Routledge.

Collingridge, D. and Reeve, C. (1986) Science and policy - Why the marriage is so unhappy. Bulletin of Science, Technology \& Society 6(4): 356-372.

Cross, J. and Street, A. (2009) Anthropology at the bottom of the pyramid. Anthropology Today 25(4): 4-9.

Curtis, V. and Cairncross, S. (2003) Effect of washing hands with soap on diarrhoea risk in the community: A systematic review. The Lancet Infectious Diseases 3(5): 275-281.

da Veiga, B., Chan, F. and McAleer, M. (2012) It pays to violate: How effective are the Basel accord penalties in encouraging risk management? Accounting \& Finance 52(1): 95-116.

Daxecker, U. and Prins, B. (2013) Insurgents of the sea: Institutional and economic opportunities for maritime piracy. Journal of Conflict Resolution 57(6): 940-965.

Dégardin, K., Roggo, Y. and Margot, P. (2014) Understanding and fighting the medicine counterfeit market. Journal of Pharmaceutical and Biomedical Analysis 87(January): 167-175.

Dore, R. (2008) Financialization of the global economy. Industrial and Corporate Change 17(6): 1097-1112.

Eltantawy, N. and Wiest, J.B. (2011) Social media in the Egyptian revolution: Reconsidering resource mobilization theory. International Journal of Communication 5, http:// ijoc.org/index.php/ijoc/article/view/1242\%3E, accessed 16 August 2015.

Erikson, K. (1994) A New Species of Trouble. Explorations in Disaster, Trauma, and Community. New York: W.W. Norton and Company.

Etges, R. and Sutcliffe, E. (2008) An overview of transnational organized cyber crime. Information Security Journal: A Global Perspective 17(2): 87-94.

Farwell, J.P. (2014) The media strategy of ISIS. Survival 56(6): 49-55.

Fischbacher-Smith, D. (2011) Destructive landscapes - (Re)framing elements of risk. Risk management 13(1-2): 1-15.

Fischbacher-Smith, D. (2014) Organisational ineffectiveness: Environmental shifts and the transition to crisis. Journal of Organizational Effectiveness: People and Performance 1(4): 423-446.

Fischbacher-Smith, D. (2015) The enemy has passed through the gate. Journal of Organizational Effectiveness: People and Performance 2(2): 134-156.

Fischer, F. (1990) Technocracy and the Politics of Expertise. Newbury Park, CA: Sage. 
Fischer, F. (2000) Citizens, Experts, and the Environment: The Politics of Local Knowledge. Durham, NC: Duke University Press.

Friedman, T.L. (2005) It's a flat world, after all. The New York Times, 3 April: 33-37.

Friedmann, T.L. (2006) The World is Flat. London: Penguin Books.

Fu, T., Abbasi, A. and Chen, H. (2010) A focused crawler for dark web forums. Journal of the American Society for Information Science and Technology 61(6): 1213-1231.

Gilmore, A.B. and McKee, M. (2004) Moving East: How the transnational tobacco industry gained entry to the emerging markets of the former Soviet union - Part I: Establishing cigarette imports. Tobacco Control 13(2): 143-150.

Grabosky, P. (2007) Requirements of prosecution services to deal with cyber crime. Crime, Law and Social Change 47(4-5): 201-223.

Greenwald, G. (2014) No Place to Hide. Edward Snowden, the NSA and the Surveillance State. London: Hamish Hamilton.

Gruner, H.S. (1996) Export of US tobacco products to developing countries and previously closed markets. Law \& Polcy in International Business 28(1): 217-254.

Gupta, S. and Jaiswal, A.K. (2013) Making the case for harming the poor - A review of marketing tactics at the bottom of the pyramid. Journal of Applied Business and Economics 14(5): 30-40.

Gurnow, M. (2014) The Edward Snowden Affair. Exposing the Politics and Media Behind the NSA Scandal. Indianapolis, IN: Blue River Press.

Hodge, B. and Coronado, G. (2007) Understanding change in organizations in a far-fromequilibrium world. Emergence: Complexity and Organizations 9(3): 3-15.

Holdaway, J.C. (2014) Watching the crew: Commercial aircraft operations and the surveillance of pilots before and after MH370. The Arbutus Review 5(1): 41-61.

Hudson, R. (2000) Production, Places and Environment. Changing Perspectives in Economic Geography. Harlow, UK: Prentice Hall.

Hudson, R. (2001) Producing Places. New York: The Guilford Press.

Hudson, R. (2004) Conceptualizing economies and their geographies: Spaces, flows and circuits. Progress in Human Geography 28(4): 447-471.

Hudson, R. (2009) The costs of globalization: Producing new forms of risk to health and well-being. Risk Management 11(1): 13-29.

Hudson, R. (2014) Thinking through the relationships between legal and illegal activities and economies: Spaces, flows and pathways. Journal of Economic Geography 14(4): $775-795$.

Idemudia, U. and Ite, U.E. (2006) Demystifying the niger delta conflict: Towards an integrated explanation. Review of African Political Economy 33(109): 391-406.

Jablonski, R.S. and Oliver, S. (2013) The political economy of plunder: Economic opportunity and modern piracy. Journal of Conflict Resolution 57(4): 682-708.

Jenelius, E., Westin, J. and Holmgren, Å.J. (2010) Critical infrastructure protection under imperfect attacker perception. International Journal of Critical Infrastructure Protection 3(1): 16-26.

Joffé, G. (2011) The Arab spring in North Africa: Origins and prospects. The Journal of North African Studies 16(4): 507-532.

Kamrava, M. (2012) The Arab Spring and the Saudi-led counterrevolution. Orbis 56(1): 96-104.

Kavanagh, J. (2011) Selection, availability, and opportunity: The conditional effect of poverty on terrorist group participation. Journal of Conflict Resolution 55(1): 106-132.

Keene, S.D. (2011) Terrorism and the internet: A double-edged sword. Journal of Money Laundering Control 14(4): 359-370. 
Kerr, R. and Robinson, S. (2011) Leadership as an elite field: Scottish banking leaders and the crisis of 2007-2009. Leadership 7(2): 151-173.

Khondker, H.H. (2011) Role of the new media in the Arab Spring. Globalizations 8(5): 675-679.

Klausen, J. (2014) Tweeting the Jihad: Social media networks of Western foreign fighters in Syria and Iraq. Studies in Conflict \& Terrorism 38(1): 1-22.

Koroma, M. and Lv, S. (2015) Ebola wreaks havoc in Sierra Leone. Infectious Diseases of Poverty 4(1): 10.

Lambert, A., Sargent, J.D., Glantz, S.A. and Ling, P.M. (2004) How Philip Morris unlocked the Japanese cigarette market: Lessons for global tobacco control. Tobacco Control 13(4): 379-387.

Lawrence, G. (2015) Defending financialization. Dialogues in Human Geography 5(2): 201-205.

Leeson, P.T. (2009) The Invisible Hook. The Hidden Economics of Pirates. Princeton, NJ: Princeton University Press.

Lemieux, A.F., Brachman, J.M., Levitt, J. and Wood, J. (2014) Inspire magazine: A critical analysis of its significance and potential impact through the lens of the information, motivation, and behavioral skills model. Terrorism and Political Violence 26(2): 354-371.

Lynch, M., Freelon, D. and Aday, S. (2014) Syria in the Arab Spring: The integration of Syria's conflict with the Arab uprisings, 2011-2013. Research and Politics 1(3): 1-7.

Mackey, R. (2015) Indian rapper calls out Unilever to a Nicki Minaj beat. The New York Times Monday 31 July, http://www.nytimes.com/2015/2008/2001/world/asia/indianrapper-calls-out-unilever-to-a-nicki-minaj-beat.html?_r=2010, accessed 20-31 August.

Manuj, I. and Mentzer, J.T. (2008) Global supply chain risk management strategies. International Journal of Physical Distribution \& Logistics Management 38(3): 192-223.

Mikes, A. (2009) Risk management and calculative cultures. Management Accounting Research 20(1): 18-40.

Minbaeva, D. and Collings, D.G. (2013) Seven myths of global talent management. The International Journal of Human Resource Management 24(9): 1762-1776.

Murphy, M.N. (2009) Small Boats, Weak States, Dirty Money: The Challenge of Piracy. New York: Columbia University Press.

O’Donnell, E. (2005) Enterprise risk management: A systems-thinking framework for the event identification phase. International Journal of Accounting Information Systems 6(3): 177-195.

Obi, C.I. (2010) Oil extraction, dispossession, resistance, and conflict in Nigeria's oil-rich niger delta. Canadian Journal of Development Studies/Revue canadienne d'études $d u$ développement 30(1-2): 219-236.

Olsen, R.A. (2011) The sin of untrustworthy financial behaviour: The American experience, 1985-2010. International Journal of Behavioural Accounting and Finance 2(3-4): 252-258.

Owens, L.A. (2012) The Polls-Trends: Confidence in banks, financial institutions, and wall street, 1971-2011. Public Opinion Quarterly 76(1): 142-162.

Peck, H. (2005) Drivers of supply chain vulnerability: An integrated framework. International Journal of Physical Distribution \& Logistics Management 35(4): 210-232.

Perrow, C. (1984) Normal Accidents. New York: Basic Books.

Pham, J.P. (2010) Putting Somali piracy in context. Journal of Contemporary African Studies 28(3): 325-341.

Pike, A. and Pollard, J. (2010) Economic geographies of financialization. Economic Geography 86(1): 29-51. 
Pocar, F. (2004) New challenges for international rules against cyber-crime. European Journal on Criminal Policy and Research 10(1): 27-37.

Power, M. (2009) The risk management of nothing. Accounting, Organizations and Society 34(6-7): 849-855.

Radell, W.W. (1992) Storming and catastrophic system failures. Industrial Crisis Quarterly 6(4): 295-312.

Radin, T. and Calkins, M. (2006) The struggle against sweatshops: Moving toward responsible global business. Journal of Business Ethics 66(2-3): 261-272.

Reason, J.T. (1987) An interactionist's view of system pathology. In: J.A. Wise and A. Debons (eds.) Information Systems: Failure Analysis: 211-220. Berlin, Germany: Springer-Verlag.

Reason, J.T. (1990) Human error. Oxford: Oxford University Press.

Reason, J.T. (1993) Managing the management risk: New approaches to organisational safety. In: B. Wilpert and T. Qvale (eds.) Reliability and Safety in Hazardous Work Systems. Approaches to Analysis and Design 7-22. Hove, UK: Lawrence Erlbaum Associates Ltd.

Reason, J.T. (1995) A systems approach to organizational error. Ergonomics 38(8): 1708-1721.

Reason, J.T. (1997) Managing the Risks of Organizational Accidents. Aldershot, UK: Ashgate.

Reason, J.T. (2000) Human error: Models and management. British Medical Journal 320(March): 768-770.

Rennen, W. and Martens, P. (2003) The globalisation timeline. Integrated Assessment 4(3): 137-144.

Routledge, P. (1996) Critical geopolitics and terrains of resistance. Political Geography 15(6-7): 509-531.

Routledge, P. (2000) 'Our resistance will be as transnational as capital': Convergence space and strategy in globalising resistance. GeoJournal 52(1): 25-33.

Routledge, P. (2003) Convergence space: Process geographies of grassroots globalization networks. Transactions of the Institute of British Geographers 28(3): 333-349.

Schuler, R.S., Jackson, S.E. and Tarique, I. (2011) Global talent management and global talent challenges: Strategic opportunities for IHRM. Journal of World Business 46(4): 506-516.

Shahid, N.S., Iii, W.B.G., Samadi, A.R., Huq, M.I. and Rahman, N. (1996) Hand washing with soap reduces Diarrhoea and spread of bacterial Pathogens in a Bangladesh village. Journal of Diarrhoeal Diseases Research 14(2): 85-89.

Shrivastava, P. (1987) Bhopal. Anatomy of a Crisis. Cambridge, MA: Ballinger Publishing Company.

Smith, D. (2005) Dancing with the mysterious forces of chaos: Issues around complexity, knowledge and the management of uncertainty. Clinician in Management 13(3/4): 115-123.

Smith, D. and Blowers, A. (1992) Here today there tomorrow: The politics of transboundary hazardous waste transfers. In: M. Clark, D. Smith and A. Blowers (eds.) Waste Location: Spatial Aspects of Waste Management, Hazards and Disposal 208-226. London: Routledge.

Sparrow, P. (2012) Globalising the international mobility function: The role of emerging markets, flexibility and strategic delivery models. The International Journal of Human Resource Management 23(12): 2404-2427.

Sridharan, S. and Viswanathan, M. (2008) Marketing in subsistence marketplaces: Consumption and entrepreneurship in a South Indian context. Journal of Consumer Marketing 25(7): 455-462. 
Stansfield, G. (2014) The Islamic state, the Kurdistan region and the future of Iraq: Assessing UK policy options. International Affairs 90(6): 1329-1350.

Stevens, T. (2009) Regulating the 'dark web': How a two-fold approach can tackle peer-topeer radicalisation. The RUSI Journal 154(2): 28-33.

Stiglitz, J. (2006) Making Globalization Work. London: Penguin.

Stokes, R. (2012) Virtual money laundering: The case of Bitcoin and the Linden dollar. Information \& Communications Technology Law 21(3): 221-236.

Tarique, I. and Schuler, R.S. (2010) Global talent management: Literature review, integrative framework, and suggestions for further research. Journal of World Business 45(2): 122-133.

Tenkorang, E.Y., Gyimah, S.O., Maticka-Tyndale, E. and Adjei, J. (2011) Superstition, witchcraft and HIV prevention in sub-Saharan Africa: The case of Ghana. Culture, Health \& Sexuality 13(9): 1001-1014.

Tenner, E. (1996) Why Things Bite Back. Technology and the Revenge Effect. London: Fourth Estate.

Tsoukas, H. (1999) David and Goliath in the risk society: Making sense of the conflict between shell and Greenpeace in the North Sea. Organization 6(3): 499-528.

Turner, B.A. (1976) The organizational and interorganizational development of disasters. Administrative Science Quarterly 21: 378-397.

Turner, B.A. (1978) Man-Made Disasters. London: Wykeham.

Turner, B.A. (1994) The causes of disaster: Sloppy management. British Journal of Management 5(3): 215-219.

Vaiman, V., Sigurjonsson, T. and Davídsson, P. (2011) Weak business culture as an antecedent of economic crisis: The case of Iceland. Journal of Business Ethics 98(2): 259-272.

van der Zwan, N. (2014) Making sense of financialization. Socio-Economic Review 12(1): 99-129.

Wainwright, T. (2012) Number crunching: Financialization and spatial strategies of risk organization. Journal of Economic Geography 12(6): 1267-1291.

Wainwright, T. (2013) Finance's outsiders?: Networks, knowledge and power beyond the City. Journal of Economic Geography 13(6): 1041-1058.

Warkentin, M. and Willison, R. (2009) Behavioral and policy issues in information systems security: The insider threat. European Journal of Information Systems 18(2): 101-105.

Watts, M. (2007) Petro-insurgency or criminal syndicate? Conflict $\&$ violence in the Niger Delta. Review of African Political Economy 34(114): 637-660.

Weick, K.E. (1988) Enacted sensemaking in crisis situations. Journal of Management Studies 25(4): 305-317.

Weick, K.E. (1990) The vulnerable system: An analysis of the Tenerife air disaster. Journal of Management 16(3): 571-593.

Weick, K.E. (1993) The collapse of sensemaking in organizations: The Mann Gulch Disaster. Administrative Science Quarterly 38(4): 628-652.

Weidner, K.L., Rosa, J.A. and Viswanathan, M. (2010) Marketing to subsistence consumers: Lessons from practice. Journal of Business Research 63(6): 559-569.

Wertheimer, A.I., Chaney, N.M. and Santella, T. (2003) Counterfeit pharmaceuticals: Current status and future projections. Journal of the American Pharmacists Association 43(6): 710-717.

Wilder-Smith, A. and Gubler, D.J. (2008) Geographic expansion of dengue: The impact of international travel. Medical Clinics of North America 92(6): 1377-1390. 
Wilmarth, A.E. (2009) The dark side of universal banking: Financial conglomerates and the origins of the subprime financial crisis. Connecticut Law Review 41(4): 963-1050.

Xu, J., Chen, H., Zhou, Y. and Qin, J. (2006) On the topology of the dark web of terrorist groups. In S. Mehrotra, D. Zeng, H. Chen, B. Thuraisingham and F.-Y. Wang (eds.) Intelligence and Security Informatics. Vol. 3975. Berlin, Germany: Springer, pp. 367-376.

Yach, D. and Bettcher, D. (2000) Globalisation of tobacco industry influence and new global responses. Tobacco Control 9(2): 206-216.

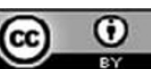

This work is licensed under a Creative Commons Attribution 3.0

Unported License. The images or other third party material in this article are included in the article's Creative Commons license, unless indicated otherwise in the credit line; if the material is not included under the Creative Commons license, users will need to obtain permission from the license holder to reproduce the material. To view a copy of this license, visit http:// creativecommons.org/licenses/by/3.0/ 